\title{
Sunni-Shia Issue in Azerbaijan
}

\author{
Ilia Brondz ${ }^{1}$, Tahmina Aslanova ${ }^{2 *}$ \\ ${ }^{1}$ Norwegian Drug Control and Drug Discovery Institute (NDCDDI), Ski, Norway \\ ${ }^{2}$ Department of History of Azerbaijan, History Faculty, Baku State University (BSU), Baku, Azerbaijan \\ Email: ailia.brondz@gmail.com, *tehmineasl@gmail.com
}

How to cite this paper: Brondz, I. and Aslanova, T. (2019) Sunni-Shia Issue in Azerbaijan. Voice of the Publisher, 5, 1-11. https://doi.org/10.4236/vp.2019.51001

Received: December 13, 2018

Accepted: March 22, 2019

Published: March 25, 2019

Copyright $\odot 2019$ by author(s) and Scientific Research Publishing Inc. This work is licensed under the Creative Commons Attribution International License (CC BY 4.0).

http://creativecommons.org/licenses/by/4.0/

\begin{abstract}
Being constitutionally recognized as a secular country, due to its Muslim majority Azerbaijan is known as a Muslim country in the world. Most of the Muslim population belongs to Shia sect, which is a minor part of Muslims all over the world and this peculiarity differentiates Azerbaijan from other Islam dominated countries. The issue of division of Islam shows itself, not that distinctly, but somehow in Azerbaijan too. Considering the geographic position of Azerbaijan that is one of the crucial factors being lucrative for the foreign actors to some extent led to an imbalance between the Sunni-Shia sects. Since the analysis of Sunni-Shia controversies, the history and spread of Islam in Azerbaijan are being studied by a number of researches, this article will not be focused on the same issues. The reason why Azerbaijan does not witness Sunni-Shia controversies comparing with other Islamic countries has always been a topic of discussion and this article aims to shed a light on some aspects of this question. However, the fact that the recent developments in rivalry between sects due to internal and foreign influences makes us concern about its nature to cause hazardous situation in all spheres of life.
\end{abstract}

\section{Keywords}

Islam, Sunnism, Shiism, Azerbaijan, Foreign Actors, Secularism, İslamic Revival

\section{Introduction (Dissemination of Islam in Azerbaijan: First Signs of Sectarian Tensions)}

Back in VII century Arabs started to storm the northern borders of Middle East as well as Azerbaijan, thus, started the spread of Islam in the territory of Modern Azerbaijan. Formation of the religion in this territory evolved through numerous steps over the centuries and has been a long complex process. The religious policy of states and nations who took control of these territories before and after 
Arabs had a huge impact not only on the ethnic identity, but on the distinction of Azerbaijani population's religious identity. It is noteworthy to mention the fact that the existence of Christianity, Zoroastrianism and Shamanism before Islam for centuries had influence on the spread of new religion in Azerbaijan. Azerbaijan as being the bridge between West and East, considering the motherland of people with Turkic origin-speaking Turkic language could not remain beyond the religious and ethnic conflicts of the medieval ages. The aggravating of the conflict was not only due to the fact that the territory was surrounded by Muslim and Christian states. At the same time, becoming the field of struggle between Sunni Turkey and Shia Iran (Iran is used as a geographic location) added the religious patter into the political controversy as well. That to a certain extent led to the ideological disorientation of Azerbaijani people. When a state founded its authority over these territories, the religion he backed also dominated the area, while other sects and their adherents by taking opposition side continued the struggle for power. In XV-XVI centuries, internal Safavids-AqQoyunlu [1] and external Safavids-Ottomans religious clashes contributed to the sectarian hostility and became an inseparable part of the history of Azerbaijan until the beginning of XIX century.

\subsection{Expansion of Sunni-Shia Division Process}

One of the interesting sides of Islam is the adaptation to the local conditions of different areas. It had spread and got various regional forms without damaging the common principles. The regional form of Islam spread in Central Asia and Caucasus, especially Azerbaijan was Islamic mysticism-Sufizm [2]. Some Sufi brotherhoods whose influence grew in XIII-XV centuries headed the main social movements in Azerbaijan, Iran and Ottoman Empire. One of them was Safaviyya brotherhood [3], which was the first to raise Irfan or Shi'ite Sufism to the rank of a state ideology in XVI century, distinguishing Iranian Turks from others. Because of this policy Azerbaijan became a battlefield for endless wars between Safavids and Ottomans in XVI-XVIII centuries. During the reign of Tahmasib I Shiism was an absolute and even radical form of this sect dominating Azerbaijan and Iran. Only his son, Ismail II showed interest to Sunnis, and tried to remove radical form of Shiism and extreme hostile attitude towards Sunnis, but he couldn't. Because of his attempts he was killed in the second year of his reign [4] [5] [6].

\subsection{Further Attempts for Reconciliation of Sunni-Shia Sects}

In XVIII century, there was a new attempt to reconcile Sunni and Shia sects of Islam by Nader Shah-the ruler of the Afshar dynasty. In 1736, Nader, the military commander from the Turkoman Afshar tribe, overthrew the rule of the Safavid dynasty by declaring himself Shah. He introduced the term "Jafari" to de-

${ }^{1}$ The term Jafarism refers to Jafar al-Sadiq, who was principally responsible for defining Twelver Shia doctrine. It is in fact synonymous with Twelver Shia Islam. 
scribe mainstream Shias by repeating Sunni methodology. He launched a series of religious reforms aimed at easing differences between Shias and Sunnis. But he failed to achieve his goal, there were few changes as Shias were allowed to join Sunnis during the Hajj pilgrimage to Mecca [7]. Nader Shah was interested in gaining rights for his people to go to the Hajj in part because of revenues from the pilgrimage trade. Among his reforms was the introduction of what came to be known as the kolah-e Naderi (Figure 1). This was a hat with four peaks which symbolized the first four caliphs. Since the times of Nader Shah, no further civil wars between Shia and Sunnis have been recorded. After his death, during the Khanates period in Azerbaijan, khanates such as Quba and Derbent, located in the north of Azerbaijan, close to Dagestan, were officially Sunni, while the southern ones were Shia, but nonetheless it didn't play a major political role [8].

\section{Islam in Azerbaijan under the Russian Empire Conquest: From the Religious to the National Identity}

Early in XIX century, Araxes river became a border between Russia and Iran after the Treaty of Turkmenchay, according to the terms, north of the Araxes was incorporated into Russian Empire and cut off from the major Shia cities of Qom, Mashhad and Tabriz. Turks remaining in the northern border of river in Russian-held Azerbaijan thoroughly differed from their compatriots remaining in the south of the river; while in the north, regions bordering with Dagestan and Chechens, also to the west part majority were Sunnis, but in the south part of Azerbaijan granted to Iran, Shi'as outnumbered Sunnis, which consequently resulted with involving North Azerbaijan in the secularization process by which to the political difference between North and South part of country was added religious factor [9]. The approach of Tsarist regime to Islam was not even, accompanied with the demonstration of tolerance to avoid forthcoming rebellions or

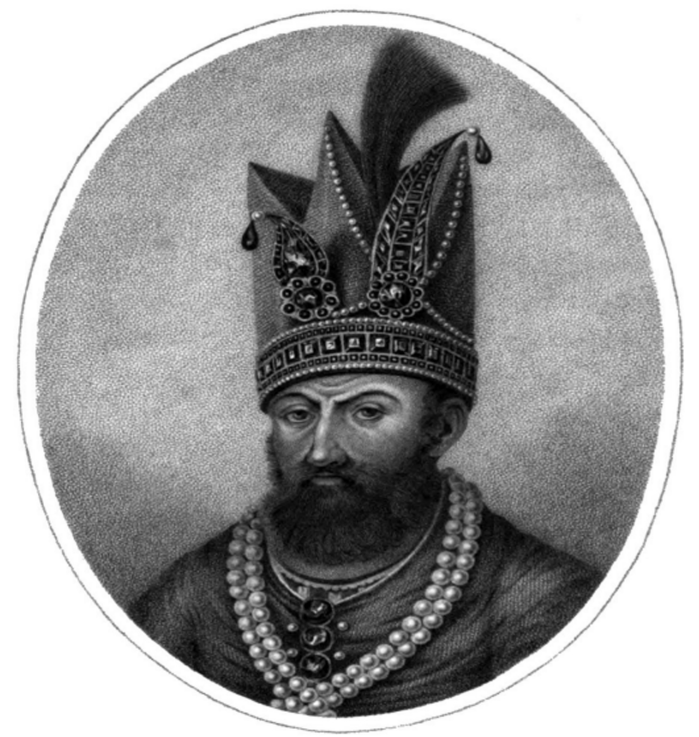

Figure 1. Nader Shah. 
when the weakness of the new government was apparent. However generally as a "rival and fanatic religion" Islam was under pressure. The state and political officials could not come to an agreement regarding the religion, although the plan on centralizing the religious governance was prepared, the Tsarist government was concerned about unifying Caucasian Muslims even under official control. In this case, the tension in North Caucasus was more apparent and long-lasted. Creating a centralized clerical board remained unsettled, while in South Caucasus "The Resolution on Board of Shiite and Sunni Muslims of Transcaucasia" was adopted by Russian Tsar in 1872. Two Muslim administrative organ-Sunni and Shi'a's Spiritual Boards respectively headed by Mufti and Sheikhul-Islam was formed. They were under the control of Ministry of Internal Affairs and directly attached to the Viceroyalty [10]. The religious issues of South Caucasian Muslims were arranged by these two boards until Azerbaijan declared its Independence (1918-1920). In the beginning periods of tsar's conquest, the Russian authorities considered Sunnis more hostile and this sentiment was reinforced by the Sunni-dominated North Caucasus. The long-lasted struggle of Imam Shamil against Russian Tsar' army inspired the Azerbaijani Sunnis whom by getting both spiritual and material support from mountainous nation started their rebellions against the regime in the 30s of XIX century. There are a number of facts prove that Russian government used even Shi'as for its purpose of neutralizing the followers of Muridism and Sunnis whose persecution changed the percentage of people in favor of Shi'as. It can be said that since this time Shi'as were composed the main part of all South Caucasus Muslims [11] [12]. Overall, the Russian Tsarist government was interested in existence of resentment among different sects (tarikas) of Islam and gave its support to some of them. This way had been estimated as an opportunity to deepen the conflicts among the sects by which Islam could internally be weakened. South Azerbaijan, ruled by Gajar dynasty was the territory where Babism and its reformist wing Bahaism widely spread and passed to the regions of North Azerbaijan, including Nakhchivan, Ordubad and namely to Baku. The Russian Tsarist regime allowed them to move from south of Araz river and be settled in the north regions of Azerbaijan by creating a favorable condition for them to spread their ideas. An orthodox Shia clericals and Islam adherents were concerned about the activity of Babis, Bahais, and the sect of Sheykhis, while the local people were seriously suffered from the internal conflicts too. The sects and split among them were openly depicted in the fictions referring to the mid-XIX century [13]. All these factors sometimes hindered Muslims to unite and solve their common problems that had been attempted to rise several times before government by February Revolution of 1917. Among these events can be listed Congresses of Russian Muslims held in 1905-1906, the activity of Muslim fraction in the Russian State Duma and etc., where regardless of inter-rivalry of Muslim nations somehow, they could make their voice to be heard [14]. During Armenian-Azerbaijanis (by then, Azerbaijanis were called Transcaucasian Muslims or Tatars) ethnic conflict during the 
Russian Revolution of 1905-1907 which was fomented by Tsarist government in order to distract the attention of subordinated nations from the social-political issues also eliminated the Sunni-Shia split, and consequently pushed Azerbaijani Muslims to merge their forces against Armenian threat regardless being bounded to Sunni-Shia sects and become the participants of the National Movement aimed to get rid of the oppression of the Russian Empire.

\section{Secularization Line: Secular Intellectuals and Their Reforms}

One of the main responsibilities of front-rank Azerbaijani intellectuals, who were the leaders of enlightenment and national-liberation movement from the second quarter of XIX century, was to suspend the Sunni-Shi'a split. By taking the pro-secularization position these open-minded people's target was not Islam itself, but hostility between the sects considering it as the main obstacle for the formation of national identity, educational development and cultural level of the nation. Even during the first Congress of All-Caucasian Muslims, which was held in Baku on 15 - 20 April, 1917, the question regarding to establishing single board for both Sunnis and Shias was put into discussion and with this, they called for the unity of all political trends by ending the sectarian rivalry. For them, the time was ripe for replacing the religious identity with the national one. In the works of these intellectuals, such as Seyyid Azim Shirvani, Sultan Majid Ganizade, Mahammad TaghiSidqi, Mirze Alekber Sabir, Mirza Fatali Akhundov, Mirza Kazem Bek, Mahammad agha Shahtakhtinski, Jalil Mammadguluzade, Hasan bey Zardabi, Abbasgulu Agha Bakikhanov-special attention was given to the propaganda of national-political revival of the nation and extent of secularization [15].

Bayram Balci, a professor studying religious issue in Azerbaijan lists the factors caused the weakening of Sharia system-Shiism in this period: if the secularization process and increasing the influence of intellectual trends comes first, he underlined the role of Pan-Turkism and Pan-Islamism ideologies also as the essential factors. The Pan-Turkists thought that the Shiism was a main obstacle for building great Turkic world, and on the other hand, pan-Islamism wanted to unite Sunni and Shia division and proclaimed the unity of Islam [16]. This tendency, as mentioned above, continued during Azerbaijan Democratic Republic (ADR) existence, the first democratic Republic in the East in 1918-1920, which resulted with the weakening influence of foreign religious forces on Islam in country. Unlike North Caucasus and Central Asia, sharia courts were replaced by secular courts in Azerbaijan as it became unacceptable to form such reliable courts on sharia rules [17].

\section{Soviets and Islam}

Despite the fact that all religions were persecuted during Soviet period, the Muslims' situation was much desperate, and they were trusted less. The reason was Soviet's belief that Islam is the main obstacle for Muslims' resistance against communism. However, their anti-religious, anti-Islam position was less effec- 
tive, this can be proved by numerous facts such as covert practice of Islamic rites. Moreover, some Muslim communists from different peripheries of the Soviet Russia who held a leading position in their countries, such as Nariman Narimanov, the first Muslim communist leader of Azerbaijan, Mir Sayyid Sultanqaliyev, Galimdjan İbrahimov in Tatarstan, Uzbeks Fayzulla Khojayev, AbdurraufFitrat in Bukhara, Kazakhs Turar Riskulovand Ahmed Baytursuncherished hope to get support for the idea of Islamic Communism [18]. Narimanov thought that state esteem for religious beliefs may help the Soviets to get support in the outskirts. Despite his opposition views against Bolsheviks, soviets tried to avoid any conflicts with Muslim nations and reduced their anti-Islam measures, even did not refuse their membership in the Communist Party, for neutralizing their influence they promoted loyal Muslim communists to the state positions. Only from the end of $1920^{\text {th }}$ they started to liquidate these local communist leaders [19]. They were labeled as a "national" communist deprecating the main part line and eliminated them from the political stage. Forming the League of the Godless, closing mosques, religious schools and courts, pursuing clergies clearly demonstrated new government's antireligious-anti-Islam position from the beginning of $1920^{\text {th }}$ [19] [20]. The hostile approach of both Tsarist and Soviet Russia toward Islam was disguised as a struggle with the superstition and backwardness of the Muslims. Despite the elimination of the religious education and the pressure on religion, the Soviets were not able to destroy the country's deeply-embedded Muslim identity, however acquired a common distinctive identity as Soviet Muslims, with this they became estranged from their ethnic brethren and co-religionists both along and across the USSR borders. Overall, estimating the result of the religious policy of Soviets in Azerbaijan nearly for 70 years it seems the strengthening of the feeling to be bound to Islam noticed before the islamophobia of Russian government, but generally as a first stage of consolidation of national-ethnic identity, this religion showed itself in the peculiarities of social and individual behavior and self-consciousness rather than in confession and strict observing religious rites. As T. Swietochovski noted the practicing religious rites limited within the family not publicly, so Islam was much more privatized than previous years. Especially, the city-dwellers revealed their Muslim identity only during the main events-such as circumcision and burial ceremony [21].

In the area of religious sects, it can be said that the secularization policy of pre-Soviet Azerbaijani intellectuals, additionally the atheist position by Bolsheviks explained the limited knowledge on Sunni-Shia rivalry and to attach themselves to any of these sects, especially noticeable among the young generation, eventually led to the dispersion of above-mentioned Soviet Muslims identity or Soviet identity of Caucasian Muslims by giving its place to the ethnic-national "Muslim" identity.

\section{The Role of Foreign Actors in Activization of Radical Islam in Modern Azerbaijan}

The dissolution of the Soviet Union is marked with the revival of Islamic values 
in Azerbaijan. What was the peculiarity of it and which religious powers were fighting for it? What kind of differences can be observed in the attitude towards Islam and its sects between the Muslim population of pre-Soviet and post 1991 Azerbaijan? As mentioned above, anti-Islam policies of the USSR abated the Islamic mainstay but could not relinquish it completely. Islam was politically so vague. Despite the fact, it kept an important part to determine cultural and national identity and classify the nation ethnically. Early years of independence witnessed the spread of Turkic values and pro-Turkish political tendencies. On the other hand, since they could not provide the society with religious knowledge, Azerbaijani Shia religious leaders lost their influence and leading position in revival. Thus, contrasting local religious communities starts to be formed eventually. Notwithstanding, those communities could not gain public support due to the same reasons and starting from mid-1990s, foreign religious groups start to grow financed by overseas countries [22] [23]. Interestingly enough, Iranian and Turkish led ideologies caused public outrage among secular Azerbaijani population due to their Sunni-Shia confronting contents. Hence, they resorted different, more effective tools to manipulate the sects. However, one cannot say that sect confrontation or differences among them were embedding. There were several reasons for that, disturbed by the foreign powers' interference, local government prepared action plans, less effective amendments in the legislatives and made it mandatory for all religious communities to be subject to the Caucasian Muslims Spiritual Board despite their different sects. Although there was some interest to get education at a university of a prestigious Islamic countries in early $90^{\text {th }}$, later due to the amendments made in the Law on Freedom of Religious Belief in 2009, the people who got religious education abroad could not act as a religious person and conduct any religious rituals, that led to the less interest to the religion among the young generation for not being lucrative area. Simultaneously, all exchange programs were terminated. In spite of these, during the first decade of XXI century, active influence of Shia sect can be observed in political processes. By all means, Shaykh al-Islām's association with Shiism was the major circumstance. With another word, political activities of Shia leaders assisted the revival of this sect. As witnessed during the recent years, government supervision on religious revival gets tighter, due to restrictions imposed by the government on Sunni Nur and Salafi communities, religious revival progresses with interruptions and stagnation [24]. In contrast to other religious groups, Nur or Nurchular, which was formed as a Turkish religious sect, is less radical and aggressive than that of radical Shi'a and Salafi schools. It is a combination of moral and ethical obligations of Muslims, and its audience includes educated strata of the Azerbaijani society. However, one of the two branches of Nurcus was called the people of Gulen or Fatullahcis (the followers of FatullahGulen), who does not limit on religious propaganda, but tries to penetrate into all areas of public-political life. To prevent their influence, 10 private schools-lyceums and 1 university attached to "ChagOyretim" company, whose administration 
and teaching staff were primarily from Turkey, were closed step by step since 2014 with the order of the Azerbaijani government, while the decision was faced with strong discrepancy among the population [25]. Despite their success in modern Azerbaijan, pre-mentioned Islamic movements are not decisive in Azerbaijan. Main reason for that is crushing secular preference over religion in Azerbaijan. On the other hand, ongoing conflict with Christian Armenia pacifies religious confrontation between sects and preserves the importance of secular national and political identity for unity. In addition, Pew Research Center's survey of 2011-2012, which was carried out in 5 countries comprising Sunni and Shia population, reveals the nation's attitude towards one another. Survey was accomplished among 5000 Muslims. Among them Shias comprise the majority in Iran, Iraq and Azerbaijan. According to the results, tension between Sunnis and Shia's was confirmed only by $1 \%$ of the respondents (Figure 2) [26].

Less tension among both sects in Azerbaijan is observed with overt practice of both religious beliefs, which are similar to each other except some key tenets of their faith. Among those rituals, remembrance of Prophet Mohammad's grandchild Huseyn's death on the $10^{\text {th }}$ Ashura day and visiting major Shia saints' graves is not contradicted excessively by any of the sects (between Shias and Sunnis +93 and +86 percentage points, respectively). Such cases prove that there is no possibility that Azerbaijan will be another potential country hosting sect clash. Both the state policy and also Azerbaijani population themselves are motivated to be tolerant and publicly express religiously tolerant position [27]. Recently Heydar Mosque was constructed in Azerbaijan, being the largest Mosque

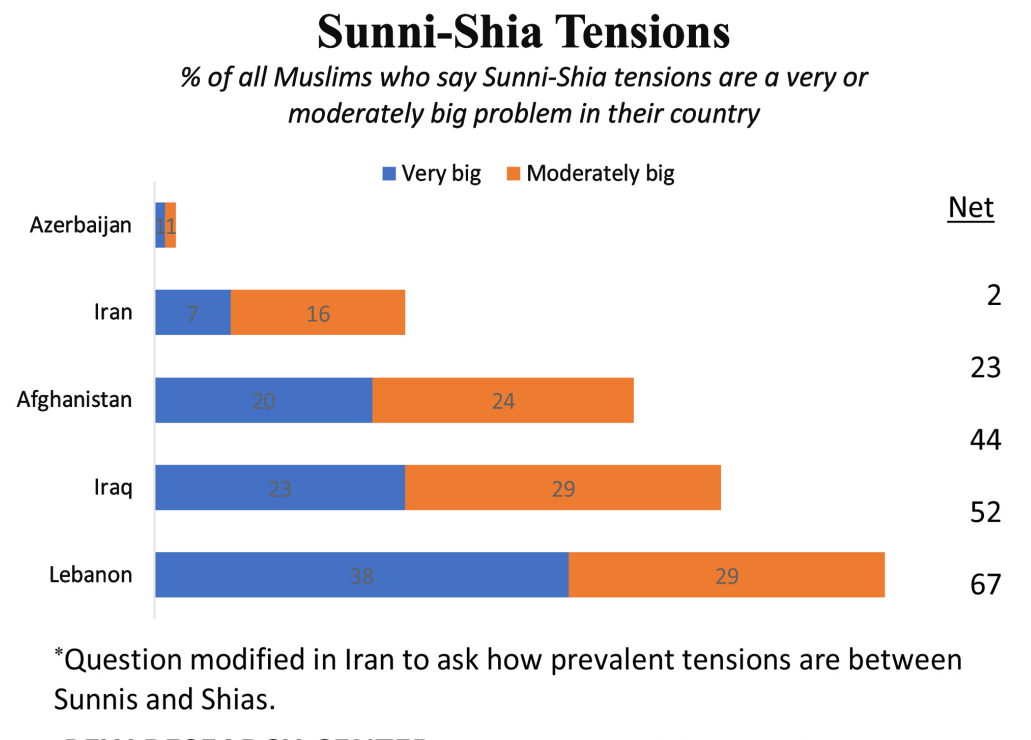

PEW RESEARCH CENTER Global Survey of Muslims Q87, Q87IRN

Figure 2. Sunni-Shia Tensions. (Figure 2 was reproduced from ref. [26] Many Sunnis and Shias Worry About Religious Conflict, (2013) Pew Re-search Center, Religion \& Public Life, http://www.pewforum.org/2013/11/07/many-sunnis-and-shias-worry-about-re ligious-conflict/). 
in the entire South Caucasus region, named after Heydar Aliyev, the third President (1993-2003) of Azerbaijan. During the inauguration, religious, government and community leaders joined together to participate in a "unity prayer" of Shia and Sunni Muslims. Since then the Heydar Mosque has been holding joint Shia-Sunni prayers every Friday https://jewishjournal.com/news/israel/185602/.

\section{Conclusion}

To conclude all the noted facts, it should be emphasized that strong political Islam does not exist in Azerbaijan. Most Azerbaijanis consider Islam as a part of their national identity and any mix of religion with the political sphere is rejected by the vast majority of people. Sparked by the USSR's collapse, Islamic revival remains rather superficial. Since the revival was boosted by foreign powers with alien ideologies to the Azerbaijani society, some differences can be seen in their attitude towards pre-Soviet Islam and its influence on society. Although, great majority associate themselves either with Sunni Islam or Shia Islam, most of them do not know the main difference between them or do not want to know at all. Yet most people even consider overtly voicing one's sect inappropriate and it does not comply with mental etiquette to them. Government-led propaganda rejecting the superiority of one sect over another and instead promoting unified and secularized Islam, thus, making religion cultural identity influences the current process as well. However, things could change. Relatively affluent natural resources of Azerbaijan (especially oil and gas) among other South Caucasian Republics attracts regional and global power's attention in this country and they try to utilize all available tools to enhance their political-economic spheres including ethnic-language and religious options. On the other hand, growing concern by the authorities over the influence of external religious influence and carrying out fierce and indiscriminate policy against some movements, along discrepancy of local population on socio-political developments might lead to the improvement of radicalization. If to express shortly, there is a serious concern for political Islam to become an influential force in Azerbaijan. In this case, many things depend on when and how the internal and foreign problems are going to be solved.

\section{Conflicts of Interest}

The authors declare no conflicts of interest regarding the publication of this paper.

\section{References}

[1] Wikipedia, the Free Encyclopedia, Aq Qoyunlu. https://en.wikipedia.org/wiki/Aq_Qoyunlu

[2] Aleskerova, N. (2007) Sufism in Azerbaijan. The Caucasus and Globalization, 1, 111-119. https://www.ca-c.org/c-g/2007/journal_eng/c-g-4/11.shtml

[3] Nazeer, A. (2001) History of Islam. An Encyclopedia of Islamic History. 
https://historyofislam.com/contents/the-land-empires-of-asia/the-emergence-of-the -safavids/

[4] Bearman, P., Bianquis, Th., Bos-worth, C.E., van Donzel, E. and Heinrichs, W.P. (2001) Middle East and Islamic Studies. Encyclopaedia of Islam, Second Edition. https://referenceworks.brillonline.com/browse/encyclopaedia-of-islam-2/alpha/i

[5] Laina, F.-H. (2002) Charles Melville, ed. Safavid Persia: The History and Politics of an Islamic Society. Comparative Civilizations Review, 47, Article 13. https://scholarsarchive.byu.edu/ccr/vol47/iss47/13

[6] Chehabi, H.E. and Mneimneh, H. (2006) Distant Relations: Iran and Lebanon in the Last 500 Years. Centre for Lebanese Studies and IB Tauris \& Co. Ltd., Oxford and London.

https://www.lebanesestudies.com/portfolio-item/distant-relations-iran-and-lebanon -in-the-last-500-years/

[7] Goyushov, A. (2012) Islam in Azerbaijan (Historical Background). The Caucasus Analytical Digest, 44, 2-4.

[8] Cornell, S.E. (2006) The Politicization of Islam in Azerbaijan. Central Asia-Caucasus Institute \& Silk Road Studies Program, Washington DC.

https://www.silkroadstudies.org/resources/pdf/SilkRoadPapers/2006_10_SRP_Corn ell_Islam-Azerbaijan.pdf

[9] Balci, B. (2004) Between Sunnism and Shiism: Islam in Post-Soviet Azerbaijan. Central Asian Survey, 23, 205-217. https://doi.org/10.1080/02634930410001310544

[10] Сампиев, И. (2008) Исторические параллели исламской политики России на Северном Кавказе. Кавказ и глобализация, 2, 63-73. (In Russian) https://cyberleninka.ru/article/v/istoricheskie-paralleli-islamskoy-politiki-rossii-nasevernom-kavkaze

[11] Swietochowski, T. (2002) Azerbaijan: The Hidden Faces of Islam. World Policy Journal, 19, 69-76. https://doi.org/10.1215/07402775-2002-4009

[12] Svanberg, I. and Westerlund, D. (1999) Islam outside the Arab World. Curzon, Richmond. https://www.amazon.com/Islam-Outside-World-Ingvar-Svanberg/dp/0700711244

[13] Ismayilova, S.A. (2016) Azərbaycan tarixinin öyrənilməsində bədii ədəbiyyat mənbə kimi (XIX əsrin II yarısı Şimali Azərbaycan bədii ədəbiyyatı üzrə), Bakalavr hazirliği üçün, Dərs vəsaiti, Azərbaycan Respublikasi Təhsil Nazirliyi, Baki Dövlət Universiteti, Avrora, Baki. Translation of Title to English: History of Azerbaijan (on the Literature of Northern Azerbaijan in the Second Half of XIX Century (2016)). The Ministry of Education of Azerbaijan Republic, Baku State University, Avrora, Baku. (In Azerbaijan)

[14] Seyidzade, D. (2011) Azerbaijan in the Beginning of XX Century: Roads Leading to Independence. Second Edition, Baku, 38-100.

http://www.anl.az/el_en/s/sd_abXX.pdf

[15] Goyushov, A., Caffee, N. and Denis, R. (2010) The Formation of Contemporary Azerbaijani Society: The Role of the Russian Conquest in the Rise of a New Elite. Azerbaijan in the World, 3, 16-17.

http://biweekly.ada.edu.az/vol_3_no_16-17/The_formation_of_contemporary_Azer baijani_society_The_role_of_the_Russian_conquest.htm

[16] Motika, R. (2001) Islam in Post-Soviet Azerbaijan. Archives de sciences sociales des religions, 115, 111-124. http://assr.revues.org/18423

https://doi.org/10.4000/assr.18423

[17] Goyushov, A. (2008) Islamic Revival in Azerbaijan. Current Trends in Islamist Ide- 
ology, 7, 66-81.

https://www.hudson.org/research/9815-islamic-revival-in-azerbaijan

[18] Баберовски, Й. (2010) Враг есть везде: Сталинизм на Кавказе, Российская политическая энциклопедия (РОССПЭН). (In Russian) http://mirknig.su/knigi/history/59414-vrag-est-vezde-stalinizm-na-kavkaze.html

[19] Беннигсен, А. (1983) Мусулманив СССР. YMCA Press, Paris. (In Russian) https://vtoraya-literatura.com/pdf/benigsen_musulmane_v_sssr_1983_text.pdf

[20] Fazlur, R. (1979) Evolution of Soviet Policy toward Muslims in Russia: 1917-1965. Institute of Muslim Minority Affairs, Journal, 1, 28-46. https://doi.org/10.1080/02666957908715792

[21] Yemelianova, G. (2014) Islam, Nationalism and State in the Muslim Caucasus. Caucasus Survey, 1, 3-23. https://doi.org/10.1080/23761199.2014.11417291

[22] Valiyev, A. (2005) Azerbaijan: Islam in a Post-Soviet Republic. Middle East Review of International Affairs, 9, 1-13.

https://www.researchgate.net/publication/293054146_Azerbaijan_Islam_in_a_PostSoviet_Republic

[23] Valiyev, A. (2005) The Rise of Salafi Islam in Azerbaijan. Terrorism Monitor, 3. https://jamestown.org/program/the-rise-of-salafi-islam-in-azerbaijan/

[24] Göyüşov, A. and Rövşənoğlu, K. (2018) The Brief History of Salafism in Azerbaijan. Baku Research Institute. https://bakuresearchinstitute.org/az/a-brief-history-of-salafism-in-azerbaijan/\#_edn 36

[25] Mammadli, N. (2018) Islam and Youth in Azerbaijan. Baku Research Institute. https://bakuresearchinstitute.org/az/islam-and-youth-in-azerbaijan/

[26] (2013) Many Sunnis and Shias Worry about Religious Conflict. Pew Research Center, Religion \& Public Life, 7.

http://www.pewforum.org/2013/11/07/many-sunnis-and-shias-worry-about-religio us-conflict/

[27] Wistrand, S.J. (2012) Azerbaijan and "Tolerant Muslims". Caucasus Analytical Digest, 44, 5-8.

http://www.css.ethz.ch/content/dam/ethz/special-interest/gess/cis/center-for-securit ies-studies/pdfs/CAD-44-5-8.pdf 